\title{
Florida Legislation Impacting Title IX
}

\author{
Ruth H. Alexander \\ Department of Exercise and Sport Sciences \\ University of Florida \\ 305 Florida Gym \\ P.O. Box 118205 \\ Gainesville, FL 32611-8205 \\ 904/392-0584
}

In the late 1970s, Florida public universities came together in an effort to resolve some of the financial needs in sports and athletics which existed when Title IX, the Education Act of 1972 was passed into law. Today, in 1995, this interest and involvement of the state legislature continues to have a positive impact in Florida institutions of education at all levels. Efforts to visit and revisit the progress that was made in early 1980 s is still an on going process of the 1990s as Title IX is strongly endorsed by the Florida legislature.

In the fall of 1980, the Board of Regents attempted to determine what was meant by "comparability" funding for women's athletics and initiated a plan to address this need. The women's athletic administrator in each of the nine universities were called together to work out a formula for such a plan. The nine universities were considered differently as four universities had football programs and five did not. The school with football were more difficult to deal with as a solution needed to be reached as to what to do with football. The large number of athletes and the expensive budgets for this sport had to be faced.

The intent was to deal with every major item in the budget and attempt to arrive at a formula which would allow the women's program comparability to the men's program. Scholarships were addressed first. The task was to determine how many full scholarships are given for each sport. For example, at this time, for men at the University of Florida:

A. Full scholarship definition (in-state) $\$ 4,200$

B. Number of scholarships permitted based on sports available for male students 155

C. Total scholarship budget is $\mathrm{A} \times \mathrm{B}=\mathrm{C}$

$\$ 651,000$
Thus, the total number of scholarship for women would be:

A. Full scholarship (in-state) $\$ 4,200$

B. Number of scholarships permitted based on sports available for female students

C. Total scholarship budget is $A \times B=C$

$\$ 394,800$

(Alexander, 1983). Thus, comparability in the scholarship budgets would result with a total of $\$ 651,000$ for men and $\$ 394,800$ for women. This means that each woman should be treated the same as each male athlete by funding scholarships to the same level for each person.

All other budget items such as supplies, uniforms, equipment, travel, awards, postage, maintenance, security, game operations, advertising, promotions, printing, publicity and all other items which were identified as a cost for men were calculated for the women's program but with a special condition for football. This special consideration for football allowed football's share, or cost, to be an average share of the other mens' sports and not the actual dollar value of football. For example:

A. Total budget of all men's programs excpet football in equipment $\$ 76,625$

B. Total number of men's sports except football

C. Average amount of budget $\$ 76,625-7=$ 10,946

D. Add the average amount to the total as football's share A+C=D $\$ 87,571$

E. Divide by the number of male athletics $D$ $318=E$

275

(Alexander, 1983). Then, using an average share for football, the $\$ 275$ was identified as amount spent on each male athlete for equipment. Thus, each woman should be the same: 
F. Number of women athletes $(123 \times \$ 275)=$ $\$ 33,871$ (Alexander, 1983). The compliance amount for women in equipment was to be $\$ 33,871$. This reveals that the same amount of money is expended on a woman athlete as for male athlete with the exception of using "an average share" for football rather than the actual budgeted amount for that sport. This procedure was followed throughout all budget line items and yielded a total compliance figure for women's athletics at each of Florida's none institutions. This amount of money was the comparability amount for women's budgets as compared to the men's budget. The current funding for women's program was subtracted from the compliance figure and then, the figure left was the amount of increase that was needed to fund women's programs in the Florida. The total amount for compliance for the institutions was approximately $\$ 3.5$ million.

In Florida, funding athletics from state appropriated sources is illegal, thus Florida Legislature had to pass a law in order for this comparability funding to occur and to assist in this major effort in the compliance with the Federal regulation of Title IX. Thus, in 1981, Florida Statute 240.2995, the Women's Intercollegiate Athletics Equity Act, was passed and signed into law by Governor Bob Graham. Florida was a "first" to accomplish such an effort for all the universities and sports magazine photographers were on the scene to watch Governor Graham sign it.

It read:

House bill 662 as passed by the 1981 Florida Legislature 240.2995 Women's Intercollegiate Athletics

(1) SHORT TITLE - This section shall be known and may be cited as the "Florida Women's Intercollegiate Athletics Equity Act."

(2) LEGISLATIVE INTENT - The Legislature recognizes that the educational opportunities for women athletes would be greatly enhanced by providing equal opportunity for women to participate in intercollegiate athletics. Therefore, it is the intent of the Legislature to demonstrate through financial assistance to the State University System and the institutions therein its commitment to the principle of equity by in- suring equal opportunity for female athletes. Furthermore, it is the intent of the Legislature that the Title IX regulations as promulgated by the United States Department of Health, Education and Welfare shall form the basis upon which appropriations are made. (Fla. Stat. $\S 240.2995,1981$ ).

A committee was also identified to "watch over" the law and to evaluate whether was being observed as it should be. In 1991, the Study Commission was directed to perform a thorough ten year study to reveal the status of women's program as compared to men's in the state of Florida.

By 1991, the Florida law had evolved into a much broader "equity" which not only included athletics, but all rights as they pertain to discriminations. The Florida Education Equity Act, 228.2001, was called Discrimination Against Students and Employees in the State System of Public Education; Prohibitions; Equality of Access; Strategies to Overcome Underrepresentation; Remedies and reads -

(3) (a) No persons shall, on the basis of sex, be excluded from participation in, be denied the benefits of, or be treated differently from another person or otherwise be discriminated against in any interscholastic, intercollegiate, club or intramural athletics offered by an educational institution and no institution shall provide athletics separately on such basis. (Fla. Stat. $\S$ 228.2001, 1991)

This particular law went on to identify in detail what colleges, community colleges, and all levels of public education must do in order to adhere to the law. The Study Commission was to review these programs by conducting a thorough survey of all the programs and to make recommendations as to the results. This process took two years to complete as the survey was very inclusive of the status of women in athletics in the state of Florida. The results showed many favorable changes had occurred but still the discrimination that still existed was glaring at some levels despite the progress which had been made.

In higher education, the programs were lacking in some areas and these were:

Salaries were higher for male coaches, particularly in basketball, than for the coaches of women's team.

Since 1970 , the number of women coach- 
ing women's team had decreased from $90 \%$ to $47.3 \%$ with an even greater decrease for women in administration. In participation, one third as many women competed and twice as many scholarships were available for men as were for women. In recruiting expenses, men spent three times as much as women in the recruiting of women athletes.

And, in support services, women were lacking in adequate health such as athletic trainers, etc. (Florida Department of Education, 1993).

In Florida Community College, a serious imbalance in number of teams for women existed in the Panhandle Conference with 13 men's teams and 7 women's teams. As a whole, the state offers $67(46 \%)$ of the athletic teams for women whereas $79(54 \%)$ is available for men. They reported only $38 \%$ of the athletic budgets is allocated to women with the $23 \%$ of the recruiting budget allocated to women while $62 \%$ of the few scholarships are awarded to men. In the Panhandle region, twice as many scholarships are awarded to men as women. (Florida Department of Education, 1993)

In coaching, half of the women's teams are coached by men with no women head coaches at seven of the schools. A major concern is the employment of full time coaches which is more like to be men. In 1991-1992 report, $78 \%$ of the head coaches of men's teams were employed full time while only $55 \%$ of the head coaches of the women's teams were employed full time. (Florida Department of Education, 1993).

In high school, Florida data reveal that $32.5 \%$ of the athletes were girls in 1991-1992, while the national percentage was $35.7 \%$. This, however, is an improvement since Title IX was passed and $89.4 \%$ of high school athletes were male, but in $1980,31.2 \%$ of the athletes were females and this has remained almost constant for more than ten years in Florida. The decline in women coaches is glaring as they have been rapidly replaced by men. The 1992 Study Commission recorded that $97 \%$ of the coaches of men's teams are male and $56 \%$ of the women's teams are coached by males. (Florida Department of Education, 1993).

Some of these problems were immediately corrected when the results of the 1991-1992 Study Commission were made known. the universities raised salaries of their coaches of women's teams, especially in the basketball and increased participation and scholarships for women by adding new teams for the women. At the University of Florida, soccer has been added and softball will be added in 1996.

High schools have also been addressed the total participation needs for girls by developing teams, especially lower level teams such as junior varsity and ninth grade teams. They also have changed to fast pitch softball rather than slow pitch in order that the girls in Florida high schools will not be at a disadvantage in receiving scholarships to NCAA schools. The NCAA only offers championships for fast pitch and not slow pitch softball.

The results of the Study Commission report in 1991-1992 prompted the more current legislation in 1993, Florida Statute 240.533, Gender Equity in Women's Intercollegiate Athletics. This bill addressed the needs of the various levels and programs in the state system. The law requires each institution to develop a plan to ensure compliance and report such findings to the Board of Regents. A punitive measure has been included in the event that these changes are not met, or at least a plan is not devised to meet them with a reasonable timetable. It reads:

Effective July 1, 1994, the Board of Regents shall withhold funds, if necessary, to ensure compliance with Title IX of the Education Amendment Act of 1972 and the Florida Educational Equity Act. (4(e) 249.533) (Fla. Stat. § 240.533, 1993).

The public school districts have also included language of a punitive nature in regard to their appropriation of funds.

The State University System, Community Colleges and public school districts are not in full compliance with the requirements of the Florida Statute but are at work on the problem everyday.

\section{References}

Alexander, Ruth H. (1983). Comparability funding in athletic programs: the Florida approach. Journal of Education Finance, 8, 523-527.

Florida Department of Education (1993). Women's and girl's participation in athletics and extracurricular activity, p. 33-35.

Fla. Stat. $\S 240.2995$, Women's Intercollegiate Athletic Equity Act 1981.

Fla. Stat. $\S 228.2001$, Florida Education Equity Act, 1991.

Fla. Stat. $\S 240.533$, Gender Equity in Women's Intercollegiate Athletics, 1993. 